\title{
Effectiveness of E-Content Module in Learning Set Language among Ninth Standard Students-Solomon Four Group Method of the Experimental Study
}

\author{
Prabakaran Ba , and Saravanakumar $\mathbf{A R}^{\mathrm{b}}$ \\ Ph.D Research Scholar, Alagappa University, Tamil Nadu, India \\ ${ }^{\mathbf{b}}$ Dean Assistant Professor, Department of Education, Alagappa University, Tamil Nadu, India,
}

\begin{abstract}
Article History: Received: 11 January 2021; Accepted: 27 February 2021; Published online: 5 April 2021
Abstract: Pedagogical methods are one of the Mathematics e-content modules of learning. The research question was raised what teaching method is more effective, whether the e-content module of learning or traditional teaching? Solomon four-group design of the experiment was managed. A convenient sampling technique is selected. Experiments are conducted in school students with 80 samples. Academic achievement test in the Mathematics unit 'Set Language' was used as a tool in the study. Bartlett's Homogeneity of Variance Test, ANOVA, and LSD post-hoc tests are used for interpretation of data. The major finding explored was that the e-content module of learning positively influenced student achievement in mathematics when compared with the chalk and talk method of teaching. A recommendation of the result was a modern pedagogical method such as an e-content module of learning which is used by the teachers in the classroom as well as the students' home for drills and practices.
\end{abstract}

Keywords: e-Content Module of Learning, Chalk and Talk Method of Teaching, Solomon Four Group Design, Bartlett's Homogeneity, LSD.

\section{Introduction}

One of the Pedagogical methods of Mathematics is an e-content module of learning. Modern technological advancement believes the subject matters can be imported through e-content learning. Mathematics is a tool for scientific communications. The alternative to the conventional method of teaching is e-content learning in modern days. Every person in the world should learn Mathematics for his/her sustainable development and survival. Mathematics influences all subjects and fields. Mathematical knowledge can be spread as awareness for escaping scientific exploitation. Mathematics is one of the compulsory subjects up to the tenth standard of general education.

\section{Need and Significant of the Study}

Set language is a branch of Mathematics that influences other fields of mathematics such as Algebra, Functional Analysis, Topology, Statistics, etc. Everything or any group of objects and living beings are expressed through the Set Language. Most of the students feel that learning mathematics is very difficult and bore the subject through a conventional method of teaching. It is a wrong notion of mathematics. Whatever, the subject delivers through the e-content module of learning to learn easily with understanding the subject concept higher than knowledge. Human is getting knowledge without the understanding of subject matter. It is easily forgettable and not applicable in life. The e-content module easily attracts the students and provides a rich experience of learning. So, the study will be proved that e-content learning is much better than the chalk and talk method of a conventional method of teaching.

\section{Research Questions}

The following research questions are raised to accomplish the objective.

1. Are four groups selected whether they have equal homogeneity and equivalent groups or not?

2. Is the treatment of the experimental groups attaining effectiveness?

\section{Hypotheses}

The following research hypotheses are formulated.

1. There are no significant differences among the variances of the four groups.

2. There are equal achievement groups of students based on their marks of the half-yearly examination.

3. There are no significant differences between the attainments of the Pre-achievement and the Postachievement of the four groups.

\section{Methodology}

Research Design 
The researcher adopted a pre-test- post-test of Solomon's four equivalent groups design in this research. One control group and one experimental group with the pre-achievement tests and the post-achievement tests are managed before and after taught through chalk and talk method of teaching and e-content development module of learning respectively. The pre-test is conducted immediately after assign the equivalent groups by using the halfyearly marks. And also, the control group and experimental group with post-achievements tests only are managed after taught through the Chalk and Talk Method of Teaching and the e-Content Development Module of learning respectively.

$\mathrm{R} \mathrm{O} 1 \times \mathrm{O} 2$

$\mathrm{R} \mathrm{O} 3 \mathrm{CO} 4$

$\mathrm{R} \times \mathrm{O} 5$

$\mathrm{R}$ C O6

In this design

1. Subjects are purposively assigned to four groups.

2. Two Groups Receive the Experimental Treatment $(\times)$.

3. One experimental group receives a pre-test (O1).

4. Two Groups (Control) do not receive treatment (C).

5. One control group receives a pre-test $(\mathrm{O} 3)$.

6. All four groups receive the post-tests $(\mathrm{O} 2, \mathrm{O} 4, \mathrm{O} 5$, and $\mathrm{O} 6)$.

7. All groups are equivalent groups.

Figure-1: Solomon Four Group Design of the Experiment

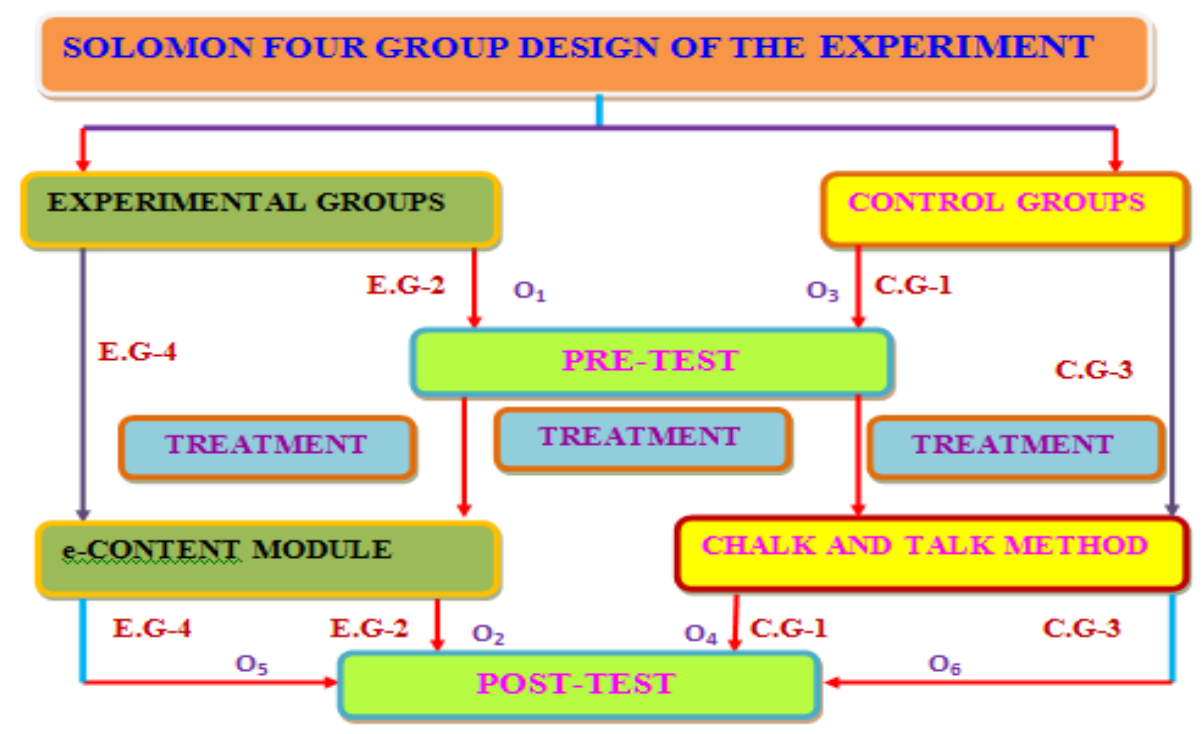

\section{The population of the Study}

Ninth standard students in the State Board of Tamil Nadu are the population for the study. Tamil medium ninth standard students in State Board of Pudukkottai District, Tamil Nadu are the accessible population for the study. Sample

Eighty 9 th standard students for 4 groups are selected for conducting experiments to the experimental groups and control groups (conventional groups) through the interactive e-content development module of learning and the chalk and talk method of teaching respectively. It means 20 students in each group are selected from one Government School and one Adi-Dravidar Welfare Schools in Pudukkottai District are the sample for the study. Four groups are purposively assigned the equivalent and homogeneous groups which were considering the halfyearly examination marks of students.

Research Teaching-Learning Module

The interactive e-content module of teaching is presented for the experimental groups and chalks and talk methods teaching is taught by the class teacher.

Research Tool 
The present study has used the following tool: Achievement Test in the Mathematics unit 'Set Language' is prepared and standardized by the investigator.

\section{Analysis and Interpretation}

Null Hypothesis-1

There is homogeneity of variances among the four groups.

Table-1: Bartlett's Homogeneity of Variance Test for Four Groups

\begin{tabular}{|c|c|c|c|c|c|}
\hline Groups & $\mathrm{N}$ & Variances & df & Bartlett's Value & p-value \\
\hline Control Group-1 & 20 & 102.2605 & \multirow{4}{*}{3} & \multirow{4}{*}{9.1442} & \multirow{4}{*}{0.0274} \\
\hline Experimental Group-2 & 20 & 317.6289 & & & \\
\hline Control Group-3 & 20 & 116.0921 & & & \\
\hline Experimental Group-4 & 20 & 111.7342 & & & \\
\hline
\end{tabular}

The table shows that Bartlett's value 9.1442 is less than the critical value 9.2100; its p-value is 0.0274 , since the P-value is bigger than the significance level (0.01), and the null hypothesis of homogeneous variances is accepted. It means the selected four groups are homogeneous.

Null Hypothesis-2

There are equal achievement groups of students based on their marks of the half-yearly examination.

Table-2: ANOVA Test for Four Groups ( $\mathrm{N}=80)$

\begin{tabular}{|c|c|l|c|c|c|}
\hline \multicolumn{1}{|c|}{ Source } & $\begin{array}{c}\text { Degrees of } \\
\text { freedom (df) }\end{array}$ & $\begin{array}{c}\text { Sum of squares } \\
(\mathrm{SS})\end{array}$ & $\begin{array}{c}\text { Means of square } \\
(\mathrm{MS})\end{array}$ & F-value & $\mathrm{p}$-value \\
\cline { 1 - 4 } Between Groups & 3 & 274.200 & 91.400 & \multirow{2}{*}{0.564} & 0.640 \\
\cline { 1 - 4 } Within Groups & 76 & 12306.600 & 161.929 & \\
\cline { 1 - 4 } Total & 79 & 12580.800 & & \\
\hline
\end{tabular}

The table shows that the calculated F-value (0.564) is less than the critical F-value (4.0503) and the calculated p-value is greater than the chosen significant level (0.01). Therefore, the hypothesis is not rejected. All four groups are achievement groups of students based on their marks of the half-yearly examination. It means they are four equivalent groups. They are perfectly chosen based on homogeneity and equivalent groups before starting the experimental procedures.

Null Hypothesis-3

There are no significant differences among the attainments of the Pre-achievement and the Post-achievement of the four groups.

Table-3: ANOVA test for Four Groups $(\mathrm{N}=120)$

\begin{tabular}{|l|c|l|c|c|c|}
\hline \multicolumn{1}{|c|}{ Source } & $\begin{array}{c}\text { Degrees of } \\
\text { freedom (df) }\end{array}$ & $\begin{array}{c}\text { Sum of squares } \\
(\text { SS })\end{array}$ & $\begin{array}{c}\text { Means of square } \\
(\text { MS })\end{array}$ & F-value & p-value \\
\hline Between Groups & 5 & 14476.6667 & 2895.3333 & 172.6929 & 0.0000 \\
\hline Within Groups & 114 & 1911.3000 & 16.7658 & & \\
\hline Total & 119 & 16387.9667 & & & \\
\hline
\end{tabular}

The table interprets that the calculated F-value (172.6929) is less than the critical F-value (4.0503) and the calculated $p$-value is greater than the chosen significant level (0.01). Therefore, there are significant differences among the attainments of the Pre-achievement and the Post-achievement of the four groups. It can be calculated the LSD-tests for further interpretation.

Table-4: Post Hoc Test of Least Significant Difference (LSD)

\begin{tabular}{|c|l|c|c|l|}
\hline Sl.No. & \multicolumn{1}{|c|}{ Between } & Difference & $\begin{array}{c}\text { Critical value of } \\
\text { LSD at } 0.01\end{array}$ & Significance at 0.01 \\
\hline 1 & Pre of C.G-1 and E.G-2 & 0.55 & 3.3920 & Not significant \\
\hline 2 & Pre of C.G-1 and post of C.G-1 & $9.15^{* *}$ & 3.3920 & significant \\
\hline 3 & Pre of C.G-1 and post of E.G-2 & $23.55^{* *}$ & 3.3920 & significant \\
\hline 4 & Pre of C.G-1 and post of C.G-3 & $15.35^{* *}$ & 3.3920 & significant \\
\hline
\end{tabular}


Prabakaran $B^{a}$, and Saravanakumar $A R^{b}$

\begin{tabular}{|c|l|c|l|l|}
\hline 5 & Pre of C.G-1 and post of E.G-4 & $28.5^{* *}$ & 3.3920 & significant \\
\hline 6 & Pre of E.G-2 and post of C.G-1 & $9.7^{* *}$ & 3.3920 & significant \\
\hline 7 & Pre of E.G-2 and post of E.G-2 & $24.1^{* *}$ & 3.3920 & significant \\
\hline 8 & Pre of E.G-2 and post of C.G-3 & $15.9^{* *}$ & 3.3920 & significant \\
\hline 9 & Pre of E.G-2 and post of E.G-4 & $29.05^{* *}$ & 3.3920 & significant \\
\hline 10 & post of C.G-1 and post of E.G-2 & $14.4^{* *}$ & 3.3920 & significant \\
\hline 11 & post of C.G-1 and post of C.G-3 & $6.2^{* *}$ & 3.3920 & significant \\
\hline 12 & post of C.G-1 and post of E.G-4 & $19.35^{* *}$ & 3.3920 & significant \\
\hline 13 & post of E.G-2 and post of C.G-3 & $8.2^{* *}$ & 3.3920 & significant \\
\hline 14 & post of E.G-2 and post of E.G-4 & $4.95^{* *}$ & 3.3920 & significant \\
\hline 15 & post of C.G-3 and post of E.G-4 & $13.15^{* *}$ & 3.3920 & significant \\
\hline
\end{tabular}

The above table interprets that

(i) The Conventional Group-1 and the Experimental Group-2 have the same achievement level at 0.01 level

(ii) Pre-achievement of the Conventional Group-1 is less than post-achievement of the Conventional Group-1. It means the treatment through the Chalk and Talk Method of Teaching is enhanced the students' achievement.

(iii) Pre-achievement of the Conventional Group-1 is less than post-achievement of the Experimental Group-2.

(iv) Pre-achievement of the Conventional Group-1 is less than post-achievement of the Conventional Group-3. It means treatment through the Chalk and Talk Method of Teaching is enhanced the students' achievement. Post-achievement of the Conventional Group-3. Here It is once again a strong conformation of treatment through the Chalk and Talk Method of Teaching is enhanced the students' achievement.

(v) Pre-achievement of the Conventional Group-1 is less than post-achievement of the Experimental Group-4.

(vi) Pre-achievement of the Experimental Group-2 is less than post-achievement of the Conventional Group-1.

(vii) Pre-achievement of the Experimental Group-2 is less than post-achievement of the Experimental Group-2. It means the treatment through the e-Content Module of Learning is enhanced the students' achievement.

(viii) Pre-achievement of the Experimental Group-2 is less than post-achievement of the Conventional Group-3.

(ix) Pre-achievement of the Experimental Group-2 is less than post-achievement of the Experimental Group-4. It means the treatment through the e-Content Module of Learning is enhanced the students'. Here It is once again a strong conformation of treatment through the e-Content Module of Learning is enhanced the students' achievement.

(x) Post-achievement of the Conventional Group-1 is less than post-achievement of the Experimental Group-2. It means the e-Content Module of Learning is increasing the learning set Language higher than the Chalk and Talk Method of Teaching.

(xi) Post-achievement of the Conventional Group-1 is less than post-achievement of the Conventional Group-3. It means the inclusive pattern of Learning is increasing the learning of Set Language through the Chalk and Talk Method of Teaching.

(xii) Post-achievement of the Conventional Group-1 is less than post-achievement of the Experimental Group-4. It means the e-Content Module of Learning is increasing the learning of Set Language higher than increasing through the Chalk and Talk Method of Teaching.

(xiii) Post-achievement of the Experimental Group-2 is greater than post-achievement of the Conventional Group-3. It means the e-Content Module of Learning is increasing the learning of Set Language higher than increasing through the Chalk and Talk Method of Teaching.

(xiv) Post-achievement of the Experimental Group-2 is less than post-achievement of the Experimental Group-4. It means the inclusive pattern of Learning is increasing the learning of Set Language higher than increasing through the e-Content Module of Learning. 
(xv) Post-achievement of the Conventional Group-3 is less than post-achievement of the Experimental Group-4. Here, confirmation of the e-Content Module of Learning is increasing the learning Set Language higher than increasing through the Chalk and Talk Method of Teaching.

\section{Finding of the Study}

(i) Conventional group-1 and experimental group-2 is the same achievement level before experimenting.

(ii) The e-Content Module of Learning is increasing the learning of Set Language higher than increasing through the Chalk and Talk Method of Teaching.

(iii) The inclusive pattern of education can be increasing the learning Set language superior to an exclusive pattern of education.

\section{Discussion of the Findings}

Findings-1 and 2

1. Conventional group-1 and experimental group 2 is the same achievement level before experimenting.

2. The e-Content Module of Learning is increasing the learning of Set Language higher than increasing through the Chalk and Talk Method of Teaching.

The following studies are supportive of findings- 1 and 2.

The Effects of Online Activities on Student Learning Outcomes in Blended Learning Environment by Herman D. Surjono (2019). The effect of online activities in a blended learning environment significantly improves students' learning outcomes in e-learning courses.

The effect of mobile learning applications on students' academic achievement and attitudes toward mobile learning by Kadir Demir and Ercan Akpinar (2018). Mobile learning can create a positive impact on academic achievement and performance and increase the motivation of students.

Impact of E-Learning vs Traditional Learning on Student's Performance and Attitude by Nahid Khalil Elfaki et al (2019). The findings revealed that the mean scores obtained by students in the final exam by the Elearning group (Experimental) are statistically significantly higher than those for the traditional group (controls) $(\mathrm{t}=3.45, \mathrm{df}=37, \mathrm{p}=0.002)$.

The Impact of Online Learning Activities on Student Learning Outcome in the Blended Learning Course by Nguyen VIET Anh (2017). Quantitative analytical results indicated that student-student interaction has a greater impact on student learning outcomes.

Study of the effectiveness of e-learning to conventional in medical undergraduates amid COVID-19 pandemic by Nimarpreet Kaur et al (2020). The study shows that online classes are effective to some extent in some parameters but inadequate in others.

The effect of web-based instruction with educational animation content at sensory organs subject on students' academic achievement and attitudes by Orhan Ercan et al (2014). There was no meaningful difference in the achievement scores between control and experimental groups prior to the study $(t(58)=0,083 ; p>0,05)$. There was a significant difference in favor of the experimental group in terms of achievement scores after the study was conducted $(\mathrm{t}(58)=3,642 ; \mathrm{p}<0,05)$.

Effect of Virtual Social Networks on Nursing Students' English Learning by Rahele Sarikhani et al. (2016). Pretest scores of the 2 groups were not significantly different, but the posttest scores of the 2 groups were significantly different $(\mathrm{P}=0.001)$.

The Impact of E-Learning on University Students' Academic Achievement and Creativity by

Zare, M. et al (2016). There is no statistically significant difference between the means of the two groups $(p=0.678)$ at entry-level based on the pretest scores. E-learning is effective for knowledge and creativity acquisitions among chemistry students and the greater e-learning opportunities should be provided for wider audiences.

Findings concerning Maths performance were consistent with other mobile learning studies (Hwang et al. 2015; Riconscente 2013). Mobile learning applications increase the effect of learning and enhance the process of learning (Huang et al., 2014; Wishart, 2015).

Finding-3

The inclusive pattern of education can be increasing the learning Set language superior to the exclusive pattern of education.

The following studies are supportive of this finding. 
Implementation of inclusive education for children with intellectual and developmental disabilities in African countries: a scoping review by Christiana Okyere et al (2019). Thirty articles that provided empirical evidence of inclusive education implementation were included. Eight articles highlighted practices that support the inclusion of children with intellectual and developmental disabilities. Using Bronfenbrenner's bioecological framework, findings revealed that inclusive education implementation is influenced by factors on the bio level, micro-level, meso level, and macro level.

Harold Smith Dawkins (2010). The impact of inclusion on the academic achievement of high school special education students. In general, biology students were positively impacted by inclusion teaching methodology because all the gaps were positive when corresponding resource years were examined.

The impact of an inclusive education intervention on learning outcomes for girls with disabilities within a resource-poor setting by Mark Carew et al (2020). Over the intervention period, girls with disabilities who participated in the inclusive education intervention obtained significantly higher English, Kiswahili, and numeracy test scores compared with a comparable group of girls with disabilities who did not participate in the intervention.

\section{Recommendation of the Study}

The e-content module of teaching and learning method is adopted in the Tamil Medium Students of the Tamil Nadu Government Schools. Many schools cannot equip with adequate facilities for delivering e-content. General Government schools are established slowly with these facilities to learn the subjects. State Government schools will be followed as educational implications of the General Government for the quality education they provide to students.

\section{Conclusion}

The experimental method is proved once again, the e-content module of learning is giving the essential support for students' learning Mathematics. They are interested, enthusiastic, and attentive learners with easy recognition and recall of the subject concepts with understanding through this method.

Disclosure statement

No potential conflict of interest was reported by the author(s).

\section{References}

BBC, (2015). Technology in schools: Future changes in classrooms: 2015. [Online] BBC.com. Available at: http://www.bbc.com/news/technology-30814302 [Accessed 29 Nov. 2016].

Christiana Okyere et al. (2019). Implementation of inclusive education for children with intellectual and developmental disabilities in African countries: a scoping review. Disability rehabilitation, 41(21), 25782595.

Creswell, J.W. (2013). Research Design: Qualitative, quantitative, and mixed methods approaches. London: Sage publications.

Deshmukh, V.M. (2012). An Efficient e-Learning System Using Web Services. International Journal of Advanced Research in Computer Science, 3(3), 853.

Duffy, T.M. and Jonassen, D.H. eds. (2013). Constructivism and the technology of instruction: A conversation. London: Rutledge.

Harold Smith Dawkins (2010). The impact of inclusion on the academic achievement of high school special education students. Doctor of Education Thesis, Gardner-Webb University 2010.

Herman, D. Surjono. (2019). The Effects of Online Activities on Student Learning Outcomes in Blended Learning Environment, 22-25.

Hosseini, T., Seyed-Saeed, Sh., Nasram, Esmailpour, M. \& Ashoori, J. (2015). A comparative study of Web-Based Education and Cognitive and Meta Cognitive Strategies on Educational Progress and Self-Efficacy of Nursing Students of Islamic Azad University, Pishva, Media Elec. Learning Magazine, 6 (2), 17-27.

Jazeel, AM. \& Saravanakumar, AR. (2015). Improving Writing Skills of PGDE Students in English through ICT-Enriched Instructional Approaches, Proceedings of International Research Conference on Humanities and Social Sciences, 123.

Keshavarz, M., Rahimi, M. \& Esmaili, Z. (2013). The Effect of E-Learning on Educational Progress of Students' Medical Science of Isfahan University. Torbat Heydarieh Uni. of Medical Science periodical, 1(2), 1322.

Manimekalai, K., \& Sivakumar, I. (2019). Clean India for New India, Chennai MJP.

Mark Carew, et al. (2020). The impact of an inclusive education intervention on learning outcomes for girls with disabilities within a resource-poor setting. African journals of disability, 4, 555. 
Nahid Khalil Elfaki, et al. (2019). Impact of E-Learning vs Traditional Learning on Student's Performance and Attitude. International Journal of Medical Research \& Health Sciences, 8(10), 76-82.

Nguyen, VIET Anh. (2017). The Impact of Online Learning Activities on Student Learning Outcome in Blended Learning Course. Journal of Information \& Knowledge Management, 16(1), 1-15.

Nimarpreet, Kaur, et al. (2020). Study of the effectiveness of e-learning to conventional teaching in medical undergraduates amid COVID-19 pandemic. National Journal of Physiology, Pharmacy and Pharmacology, 10(07), 563-567.

Khristin, Fabian, et al. (2018) Using mobile technologies for mathematics: effects on student attitudes and achievement. The use of mobile technologies elicits positive responses from students. Education Tech Research Dev, 66, 1119-1139.

Orhan, Ercan. et al. (2014). The effect of Web-Based Instruction with Educational Animation Content at Sensory Organs Subject on Students' Academic Achievement and Attitudes. Procedia - Social and Behavioral Sciences, 2430-2436.

Padmini Devi, KR. \& Saravanakumar, AR. (2017). Cognitive dissonance, locus of control, self-efficacy and academic performance of novice teachers, Indian Journal of Research, 6(2), 28-31.

Prabakaran, B., \& Saravanakumar, AR. (2020). Challenges of E-Content Development Module of Teaching and Learning, Sambodhi, 43(4), 70-72.

Prabakaran, B. \& Saravanakumar, AR. (2020). E-Content Module is Enhancing the Achievement and Retention Ability in Mathematics among High School Students, Wesleyan Journal of Research, 13(45), 27-38

Prabakaran, B. \& Saravanakumar, AR. (2020). Effectiveness of Interactive E-Content Module in Enhancing Students' Achievement in Mathematics. International Journal of Control and Automation, 13(2s), 84-94.

Prabakaran, B. \& Saravanakumar, AR. (2020). An Interactive E-Content Module for Learning Mathematics -A Single Group Experiment, International Journal of Advanced Science and Technology, 29(5s), 1297 1313.

Radha, R., Mahalakshmi, K., Sathish Kumar, V. \& Saravanakumar, AR. (2020). E-Learning during Lockdown of Covid-19 Pandemic: A Global Perspective. International Journal of Control and Automation, 13(4), 1088-1099.

Ramesh Kumar, K., Sivakumar, I., Saravanakumar, N., \& Sathishkumar, R. (2020). Regional Disparities and Indian States: A Macro Level Study, Journal of Critical Reviews, 7(13), 87-92. doi: $10.31838 /$ jcr.07.13.13

Ravichandran, T. \& Saravanakumar, AR. (2013). Enhancing Biological Sciences Laboratory Experimental Skills through Virtual Laboratory Techniques. Indian Journal of Research. 2(4), 70-72

Saravanakumar, AR. \& Subbiah, S. (2011). Teacher Education Programme through Distance Mode a Technological Approach. Indian Journal of Applied Research, 1(3), 56-57.

Saravanakumar, AR. \& Padmini Devi, K.R. (2020). Indian Higher Education: Issues and Opportunities. Journal of Critical Reviews, 7(2), 542-545.

Saravanakumar, AR. (2018). Role of ICT on Enhancing Quality of Education, International Journal of Innovative Science and Research Technology, 3(12), 717-719.

Saravanakumar, AR. Paavizhi K., \& Balamurugesh, KR. (2020). A Survey on Effectiveness of Video-Assisted Learning in Enhancing Knowledge Competencies for Teachers, Test engineering and management, 82, 5866-5872.

Saravanakumar, AR. Paavizhi, K. \& Palanisamy, P. (2019). Effectiveness of Video-Assisted Learning Module, International Journal of Control and Automation. 12(06), 268-275.

Saravanakumar, AR. (2008). Effectiveness of Motivational Strategies on Enhancing Academic Achievement, Journal of Research and Reflections on Education, 16(2).

Saravanakumar, AR. (2016). Role of ICT in transforming Sri Lankan Higher Education, International Journal of Advanced Research Trends in Engineering and Technology, 3(20).

Saravanakumar, AR., Paavizhi, K., \& Palanisamy, P. (2019). Effectiveness of Video-Assisted Learning Module. International Journal of Control and Automation, 12(06), 268-275.

Saravanakumar, AR. (2014). Present Scenario and Future Prospects of Higher Education in India. Proceeding of the Social Sciences Research ICSSR, Kota Kinabalu, Sabah, Malaysia. Organized by http://WorldConferences.net. 
Saravanakumar, AR. \& Paniadima, A. (2017). Cognitive Dissonance, Locus of Control, Self efficiency and Academic Performance of Novice Teachers, Journal of Research and Reflection of Education, 6.

Saravanakumar, AR. \& Padmini Devi, KR. (2020). Indian Higher Education: Issues and Opportunities, Journal of Critical Reviews, 7(2), 542-545.

Subbiah, S., Saravanakumar, AR. \& Perumal, R. (2012). Multidimensional practices in teacher education (TE) through distance education (DE), Indian Streams Research Journal, 1(2), 1-4.

Shandru, Mariyadas. \& Saravanakumar, AR. (2021). Conflicts between Staff: Causes and Effects of School's Activities, Indian Journal of Natural Sciences, 11(64), 1-7.

Sivakumar, I. \& Anitha, M. (2014). "Girl Children and Education an Empirical Study in Puducherry", Modern Education: Women and Weaker Section (eds), Chennai: MJP, 133-142.

Sivakumar, I. \& Usha, VT. (2013). "Educational Status of Women in Marine Fishing Community in Puducherry Region", Women and Society (eds), New Delhi: APH, 175-184.

Zare, M. et al. (2016). The Impact of E-Learning on University Students' Academic Achievement and Creativity, Journal of Technical Education and Training, 8(1), 25-33. 